\title{
CONTRIBUTION TO THE BACTERIAL FLORA OF THE SYDNEY WATER SUPPLY, II.
}

\section{By R. Greig Smith, M.Sc., Macleay Bacteriologist to the Society.}

Many pathogenic bacteria have been separated from water or from mud lying beneath well and river waters by inoculating the water, either before or after concentration, or the mud, directly into the tissues of animals in which the non-pathogenic organisms disappear whilst the pathogenic bacteria multiply and produce their characteristic lesions. Several pathogenic bacteria have been discovered in this way, as for example, Bac. cuniculicida and Bac. hydrophilus fuscus. This method, however, is only applicable in the separation of organisms pathogenic to animals, and is of no use for organisms such as Bact. typhi and Vibrio cholerce, which are parasitic in man only. The former organism is perhaps the most to be feared in the water of this country. The latter is fortunately still a stranger. Before going further, it may be said that the separation of Bact. typhi is extremely difficult, so much so, that except in cases where there is gross pollution with typhoid dejecta the organism cannot be separated. The difficulty is due perhaps to our methods, or perhaps to the fact that by the time the water is suspected the contamination has passed away after having produced the harm, and consequently the bacteriologist cannot find the causative organism in the water.

The methods that have been suggested for isolating the organism depend upon the inability of the commonly occurring water bacteria to grow upon certain media in which the typhoid and intestinal bacteria grow pretty freely. To this latter group of bacteria belong Bact. coli commune and its allies, which, unfortunately, are more resistant to chemical agents than Bact. 
typhi itself. On this account the most that can be done is to eliminate as far as possible the harmless bacteria and investigate the others. Many processes have been recommended for this purpose, and of these some have been shown to be worthless, whilst others are apparently of some value. The methods depend upon the inability of the water bacteria to grow upon special media or ordinary media with the addition of (1) phenol, (2) acids, (3) alkalies, or (4) salts.

The addition of phenol or carbolic acid to ordinary media or to special media has been most frequently advised, and in enumerating the various methods a beginning may be made with it. Dunbar has shown that the growth of the typhoid bacterium is interfered with by the presence of $0.116 \%$ of phenol in water or nutrient media, while $0 \cdot 144$ checks the growth entirely. In publishing these facts he showed the uselessness of some methods in which percentages of phenol greater than $0 \cdot 116$ were employed for the separation of Bact. typhi. A method devised by Vincent is not open to Dunbar's objection.

Vincent's method.-Five drops of a 5\% solution of phenol are added to tubes containing 10 c.c. of nutrient bouillon, and into these small increasing quantities of the water under examination are introduced. The tubes are incubated at $42^{\circ} \mathrm{C}$., and any that show a growth are used for the preparation of plates of solid media. The colonies that grow in the plates are examined and the bacteria determined by the appearances and reactions of subcultures. Bandi* also advises the employment of phenol, but at a comparatively high temperature.

Bandi's method.-200 c.c. of bouillon are added to 2 litres of water and the mixture is incubated for 5 hours at $45^{\circ} \mathrm{C}$. Twelve drops of the mixture are then added to 10 c.c. of peptone-free bouillon, together with 5 drops of $5 \%$ phenol. From the culture twelve successive transfers are made into the carbolised medium, the cultures being maintained at $45^{\circ} \mathrm{C}$. The twelfth subculture

\footnotetext{
* Bandi, Centralblatt für Bakt. 1 Abt. xxiv., 585, Ref.
} 
is inoculated into peptone-free bouillon without phenol, and after growing at $45^{\circ}$ is used to inoculate ordinary gelatine in which the typh $i$ colonies grow slowly. A method very similar, but at a lower temperature, is employed by Jordan* for the separation of Bact. coli and the elimination of other glucose fermenting bacteria, e.g., Bast. cloaca.

Jordan's method.-A quantity of the suspected water is incubated with acid meat extract and with phenol in the proportion of 1 to 1000 of fluid. The incubation is continued for 12 to 18 hours at $38^{\circ}$ to $40^{\circ} \mathrm{C}$., when the culture is used to infect plates of litmus-lactose-agar. The colonies that redden the medium are picked out and the bacteria proved by their faculty for coagulating milk, producing indol in bouillon, fermenting glucose and not peptonising gelatine. The employment of litmus-lactoseagar considerably lightens the work of separation. The use of phenol by itself has not found so much favour among bacteriologists as a mixture of phenol and hydrochloric acid which was introduced by Parietti.

Parietti's method.-A solution is prepared containing $5 \mathrm{grm}$. phenol, 4 grm. hydrochloric acid, and $100 \mathrm{grm}$. distilled water. Tubes containing 10 c.c. nutrient bouillon are treated with 3,6 , and 9 drops of the prepared solution and are then incubated for 24 hours at $37^{\circ}$ C. to make sure that no organisms have gained access during the addition. Into the sterile tubes which are placed in sets of three, a varying number of drops of the water are added, and after shaking, they are placed in the incubator at $37^{\circ} \mathrm{C}$. for 24 hours. Some of the tubes become turbid, and those that contain the greatest number of drops of solution and generally the smallest quantity of water are taken and subcultures made in order to diagnose the vegetating microbes. Frankland $\dagger$ has pointed ont that the incubation period should be prolonged for from 48 to 72 hours. Hankin $\ddagger$ uses Parietti's solution, but

* Jordan, Centralblatt für Bakt. 1 Abt. xxvii., 679, Ref.

† Frankland, Micro-organisms in Water.

$\ddagger$ Hankin, Centralblatt für Bakt. 1 A bt. xvii., 544 . 
he has modified the method to ensure the growth of Bact. typhi. Instead of taking for further examination the turbid bouillon containing the greatest number of drops of phenol solution, he takes the tube next lower in order; on the other hand, to obtain Bact. coli commune he uses the tube containing most disinfectant. The details of the method are here given briefly.

Hankin's modification.-To five tubes each containing 10 c.c. of ordinary nutrient bouillon are added $0,1,2,3$ and 4 drops of Parietti's solution and a few drops of the suspicious water. A water which contains comparatively few bacteria is filtered through a procelain candle and the microbes upon the porcelain surface brushed into a few c.c. of sterile water, which is used for infecting the bouillon. The tubes are incubated for 24 hours at $37^{\circ}$; at the end of this time an observation is made and one of the series is taken for further cultivation. The turbid tube containing the greatest number of drops of disinfectant is discarded, excepting when Bact. coli commune is sought for. Generally the turbid tube next in order is taken unless it has a thick scum upon the surface, or it has a growth visible only in the deeper layers of the liquid, or when bubbles of gas are apparent in the medium. In the latter cases the choice should fall upon a tube which is uniformly turbid. The tube that is taken is used to start a fresh series of bouillon cultures, the lowest member of which has the same number of drops of Parietti's solution as the tube taken. The process of selection is repeated upon these tubes after a 24 hours' incubation. A third series may be prepared, but usually one of the second series is used for making a smear culture on a fairly dry agar slope. Any suspicious colonies that grow on the sloped surface are inoculated into litmus-agar tubes and further examined.

Hilbert* criticised Hankin's method unfavourably, so far as it relates to the separation of Bact. typhi. He found that drops of a typhi suspension prepared by diluting a 24 hours' bouillon

* Hilbert, Centralblatt für Bakt. 1 Abt, xxvii., 526. 
culture 100,000,000 times, produced cultures of the organism in tubes containing 3 drops of Parietti's solution. In the presence of Bact. coli commune, however, Bact. typhi could not be found even in suspensions diluted only 100 times. It is apparent, that in diluted Parietti's fluid, coli prevents the growth of typhi.

Wittlin* in testing the effect of 3 to 7 drops of Parietti's solution in 10 c.c. of fluid found that the ordinary water bacteria, whose presence in water is unimportant, either do not develop or grow very feebly. The latter fact was made evident by the motile bacteria becoming non-motile. On the other hand, the pathogenic bacteria, as well as those which normally inhabit the animal intestine, are quite unaffected by the acid phenol solution. The coli group are indifferent to 7 drops of solution per 10 c.c. Similarly the bacteria of the excrement, e.y., Staphylococcus aureus, Streptococcus erysipelatis, Bact. pyocyaneum and Bact. ochraceum are unrestricted in their development. After standing in the acid medium, motile bacteria gradually lose their motility, the saprophytes becoming motionless much sooner than the pathogenic organisms with the exception of Bact. pyocyaneum. Wittlin grew many bacteria in pure culture in carbolised bouillon and noted the growth on the first or second day. Development always occurred with those bacteria which are not influenced by the reagent, however small the number of cells originally taken. This was especially the case with Staphylococcus albus and aureus, Streptococcus, Proteus immobilis, Bact. pyocyaneum, typhi, coli comm., and its varieties as well as the thrush fungus. Parietti's solution, however, is useless for isolating Bact. typhi, - because in its presence many other bacteria grow more luxuriantly, that is to to say, typhi is more susceptible to the disinfecting action of the solution than many other bacteria as, for example, the various species of coli. Wittlin arrived at the conclusion that Parietti's solution, though useless for separating Bact. typhi from water, was yet of great service for separating other pathogenic bacteria.

* Wittlin, Centralblatt für Bakt. 1. Abt. xx., 710 . 
Potassium iodide appears to be most serviceable in aiding the growth of Bact. typhi, or what is practically the same thing, checking concomitant bacteria to such an extent as to render the isolation of colonies of typhi an easier matter than would obtain in media devoid of this salt. It is used in conjunction with a potato medium which was introduced into bacteriology by Holz. The preparation of the potato medium, however, as recommended by Elsner, to whom we are indebted for the employment of potassium iodide, differs slightly from that recommended by Holz.

Elsner's method.*-Potatoes are washed, pared, and finally grated; a litre of water is added for every 500 grams of the pared potatoes and the suspension is pressed through a cloth. The strained fluid is allowed to stand overnight and then it is filtered. The filtrate is boiled and again filtered. Ordinary gelatine is dissolved in the extract, when it will be found that every 10 c.c. of the potato-gelatine requires from 2.5 to 3 c.c. of tenth normal alkali to neutralise (using phenolphthalein as the indicator); 10 c.c. portions of the gelatine are put into tubes and sterilised. When required, 1 c.c. of sterile, $10 \%$ potassium iodide is added to the molten gelatine and plates are made after infection. On the plates, Bact. coli commune grows to the exclusion of other bacteria, as large colonies in 24 hours, while Bact. typhi produces small, clear colonies like drops of water in 48 hours. The latter are finely granular, while the former are brownish and coarsely granular.

Elsner used potassium iodide as a result of experiments conducted with various chemicals, salts, resins, alkaloids and amidobodies. Of those which he tried - in number they came to many hundreds - potassium iodide together with an acid medium was found to be the best for differentiating between the typhoid and colon varieties of bacteria and for excluding others. This method is used chiefly for detecting typhi in faeces, but Remlinger and Schneider $\dagger$ have used it in testing waters and soils. Kübler and

* Elsner, Centralblatt für Bakt. 1 Abt. xvii., 591, Ref.

† Remlinger und Schneider, Centralblatt für Bakt. 1 Abt. xix., 244, Ref. 48 
Neufeld* were able by this method to separate Bact. typhi from a polluted water. Bact. coli was not present, from which they concluded that the pollution had been caused by the access of the urine of typhoid patients.

Other writers have experimented with the selective action of salts, acids, and alkalies in separating typhi and coli from water. Uffelmann $\dagger$ found that the former could withstand considerable quantities of citric acid, acetic acid or alum. He advised the addition of $10 \%$ citric acid and $0.25 \%$ methylviolet to ordinary nutrient gelatine. Dunbar, however, objected to his method, as it did not distinguish between coli and typhi. Riedal + proposed the use of iodine trichloride. Köhler§ showed the action of various organic and inorganic acids, alum, phenol, the alkaline hydrates and stains upon the growth of typhi. Fermill has recorded the resistance of various bacteria to increasing doses of certain chemicals. The bacteria are chiefly pathogenic, and although the table can be used for separating the bacteria of certain groups, yet there is no indication of the usefulness in isolating noxious from innocuous water bacteria that might have been expected from a paper which entailed a vast amount of work. There are some points, however, that may be noted, The micrococci (including the pyogenic varieties) may be separated from other bacteria by growth upon agar containing up to 10 drops of potassium hydrate in every 5 c.c. of medium. Bact. typhi has little power of resistance towards most chemicals. The varieties of Bact. coli commune and the fluorescent bacteria can withstand up to 10 drops of $5 \%$ (presumably by weight), of hydrochloric acid per 5 c.c. agar. Bact. coli commune begins to be affected when 10-16 drops of $5 \%$ potassium iodide are added to 5 c.c. agar, while Bact. typhi is affected when 5-6 drops are

* Kübler und Neufeld, Zeit. für Hygiene, xxxi., 133.

† Uffelmann, Centralblatt für Bakt. 1 Abt. xi., 218, Ref. $\ddagger$ Riedal, see Holz, Centralblatt für Bakt. 1 Abt. ix., 293, Ref.

§öhler, Centralblatt für Bakt. 1 Abt. xiv., 89, Ref.

|| Fermi, Centralblatt für Bakt. 1 Abt. xxiii., 208, 266. 
added. Billings and Peckham* found that Bact. typhi and coli commune were more resistant to the antiseptic action of light than water bacteria.

Marpmann $\dagger$ has described a method which he employs for separating three noxious classes of bacteria from water. To the water is added an equal quantity of neutral bouillon, and the mixture is incubated at $30^{\circ} \mathrm{C}$. for 24 hours in order to increase the numbers of the bacteria. At the end of this incubation period, a portion of the mixed culture is inoculated into nutrient gelatine containing $0 \cdot 2 \%$ citric acid and maintained at $20^{\circ}-22^{\circ} \mathrm{C}$. The colonies that grow are examined for Bact. typhi. Another portion is inoculated into gelatine containing $2 \%$ sodium carbonate and kept at $10^{\circ}-18^{\circ} \mathrm{C}$. The colonies are examined for cholera vibrions as well as the cloaca bacteria, which include the putrefactive microbes commonly found in the animal intestine, the representative organism being Bact. coli commune. Another portion is inoculated into nutrient agar containing $2 \%$ sodium carbonate, kept at $30^{\circ} .37^{\circ}$ and examined for cadaver bacteria. The last two groups are really subdivisions of one which includes all intestinal (sewage, excrement, etc.) bacteria. They induce a foul or putrefactive fermentation of albuminoids and carbohydrates.

Theobald Smith $\ddagger$ separates Bact. coli commune by adding quantities of the water varying from $0 \cdot 1$ to 1 c.c. to 10 fermentation tubes containing $1 \%$ glucose bouillon. In the presence of coli 40 to $60 \%$ of the volume of the tube contains gas in from 3 to 4 days. The reaction of the medium becomes strongly acid ( 5 c.c. tenth normal alkali are required to neutralise 10 c.c.). Plates are prepared from the most probable tubes before the end of a week. It is to be noted that a production of gas and acid, very similar to Bact. coli commune, is produced by varieties of Proteus, Bact. cloacce and the Bact. lactis aerogenes group of bacteria.

* Billings and Peckham, Centralblatt für Bakt. 1 Abt. xix., 244, Ref.

†Marpmann, Centralblatt für Bakt. 1 Abt. xvii., 362.

‡ Theobald Smith, Centralblatt für Bakt. 1 Abt. xviii., 494, Ref. 
Pakes* adds the suspected water to Kitasato's sodium formateglucose-bouillon. This is prepared by adding $2 \%$ glucose and $0.4 \%$ sodium formate to ordinary bouillon, and after neutralising adding 2 c.c. normal sodium hydrate (presumably to every 100 c.c. medium). The medium is boiled, filtered, placed in test tubes and sterilised. After adding a certain quantity of water or a bacterial suspension representing a quantity of the water, the bouillon tubes are placed in Buchner's tubes and incubated under anaerobic conditions at $42^{\circ} \mathrm{C}$. until the medium becomes turbid. If no growth is apparent after 72 hours the tubes are thrown away. Those which show a growth are used for making further.cultures on ordinary gelatine and agar. By this method Bact. coli comm. is generally found in nearly pure culture. With regard to the value of the separation he considers that when coli is found in quantities of water up to 20 c.c. the water should be condemned; in from 20-50 c.c. the water is suspicious; between 50 and 100 c.c. it is slightly suspicious; and in quantities greater than 100 c.c. it is probably safe. When none can be discovered in two litres the water is absolutely safe. The presence of coli in water from a deep well is enough to condemn.

Although most of the methods suggested for the selective examination of water have for their object the separation of Bact. typhi, yet it is practically agreed that they fail in their object unless these organisms are present in overwhelming quantities. Most of the methods, however, are, to a certain extent, successful in aiding the separation of Bact. coli commune, which, when found in certain quantities of water, indicate pollution, and therefore the possible presence of Bact. typhi, especially when cases of typhoid fever appear among those who have used the water. If typhoid bacteria are suspected to be in a water, and Bact. coli commune is found in a certain volume, it is probable that Bact. typhi is or has been present. As an instance, Clark and McGaget could not find Bact. typhi in the Merrimack River

* Pakes, Brit. Med. Journal, 1900, 188.

+ Clark and McGage, Centralblatt für Bakt. 1 Abt. xxvii., 678, Ref. 
water, but they showed that during the times that the Lawrence city filters were undergoing repair, the mortality from typhoid fever rose, and this occurred simultaneously with a rise in the numbers of Bact. coli commune in the water. When this organism could no longer be found in 1 c.c. of the water the epidemic ceased.

Of the microbes found in various waters some are pathogenic, others are not. In the Thames River water, Marshall Ward* separated a number of organisms which were more or less pathogenic to guinea-pigs. The most strongly pathogenic forms were those that resembled $B$. coli commune so closely as to suggest to that author that they had been derived at some time from that organism and had been modified in their cultural characters, etc., by environment, i.e., by their having been immersed in water for a more or less prolonged time. More recently, Weissenfeld $\uparrow$ has shown that varieties of coli can be obtained from many waters that are undoubtedly pure, and that these varieties are more or less pathogenic when inoculated into the tissues of guinea-pigs. From this it would appear that the reaction of a bacterium when innoculated into animals is no criterion as to the purity of the water containing the organism, that is to say, that the pathogenicity of the coli-like and other forms tells us nothing about the value of the water for dietetic purposes.

The usual method employed for getting the micro-organisms which are suspended in a large quantity of water into a smaller and workable volume consists in filtering 2, 3 or 5 litres through a porcelain filter, and in brushing the organisms from the surface of the filter into a small quantity, say 10 c.c. of sterile water. Aliquot portions of the 10 c.c. represent parts of the original quantity taken. An alternative method has been recommended by Zikes $\ddagger$ The bacteria are entangled in a precipitate of aluminium hydrate, formed by the addition of sterilised solutions

* Marshall Ward, Proc. Royal Society, No. 376, p. 417 (1897).

+ Weissenfeld, Zeitschrift für Hygiene, xxxv., 78.

† Zikes, Jour. Soc. Chem. Industry, xix., 364, Abs. 
of alum and sodium carbonate to the water. The suspension is centrifuged and the precipitate dissolved in a small quantity of $1.5 \%$ potassium hydrate; this does not affect the vitality of the bacteria which are then cultivated. From 96 to $100 \%$ of the micro-organisms present in the water can be obtained by this method.

The Sydney city water was tested by the various methods, and the organisms that were brought into prominence by the individual schemes were studied in detail. Taken as a whole, the bacterial flora that survives treatment with disinfectants is limited. In the tests the water, as a rule, was passed through a porcelain filter, and the bacteria brushed from the surface of the candle with a sterile stiff brush into 10 c.c. of sterile water. Various quantities of the suspension were used.

The three methods of Vincent, Bandi, and Jordan are very similar, and as the two latter are the more recent and improvements upon the former, they alone were tried. By Bandi's method the first tube of carbolised meat extract only became turbid, succeeding tubes failed to show a growth. There was only one kind of organism in the turbid tube. The temperature of $45^{\circ} \mathrm{C}$. appears to be too high for the growth of species of Bact. coli, especially under such unfavourable circumstances as obtain in carbolised media. As we shall see later, Bact. coli would be present in the quantity of water employed, viz., 2000 c.c. In using Jordan's method the plates containing the equivalent of 20 c.c. of water and upwards became turbid, and plates infected with the growth from 20 c.c. and 200 c.c. grew similar colonies. From these two suspicious kinds of colony were picked out. They were suspicious because they appeared to produce acid in the litmus-lactose medium. In the one case this appearance was caused by the red colour produced by the organism itself, which proved to be Bact. miniaceum. The other was a micrococcus which appears to be Mic. pyogenes $\gamma$ albus. By raising the incubation temperature to $42^{\circ} \mathrm{C}$. no growth was obtained in the tubes even with the equivalent of 800 c.c. of water. A repetition 
at a later date with the equivalent of 2000 c.c. of water was likewise found to be sterile. This fact is rather curious, because a culture of Bact. coli commune isolated from faeces grew to a considerable extent in the medium at $42^{\circ}$. It probably indicates that the varieties of Bact. coli that are present in the water (and a variety was found in 800 c.c. on the same date as the repetition) are considerably weakened, so much so as to be unable to grow in Jordan's medium at $42^{\circ} \mathrm{C}$.

With a water temperature of $13^{\circ} \mathrm{C}$. (end of August) no growth was obtained in tubes containing 7 drops of Parietti's solution to every 10 c.c. of a mixture of bouillon and bacterial suspension, even when the equivalent of a litre of water was employed. Growth was obtained later in the year (middle of October) when the temperature of the water had risen to $17^{\circ} \mathrm{C}$. To tubes containing 10 c.c. of bouillon were added 1.5 c.c. portions of bacterial suspension (representing 300 c.c. of water) and from 1 to 6 drops of Parietti's solution. The tubes were incubated at $37^{\circ} \mathrm{C}$. A turbidity and surface film appeared in each, and as time went on the film became black. Plates which were infected with the 4 and the 6 drop growth produced colonies which appeared like drops of gum. This organism was proved to be Bac. mesentericus niger, Lunt, a recently discovered potato bacillus. Using the same quantities of bouillon and bacterial suspension growth occurred in the presence of 9 drops of Parietti's solution, but 9 drops appeared to be the limit for the quantity of suspension employed, as the tube with 10 drops remained clear. With regard to the ratio between Parietti's solution and the infected medium, the dropping pipette delivered 36 drops to the c.c. (grm.) and the bouillon mixture measured 11.5 c.c The plates that were prepared with the cultures in the 7 and 9 drop tubes produced what appeared in each case to be a pure culture of Bacterium I. This organism appears to be Bac. aquatilis communis. In a test made at a later date, when the temperature of the water had risen to $22^{\circ} \mathrm{C}$., colonies of Bact. coli commune were found in plates which had been prepared from a 24 and a 48 hours' culture in 8 drops of Parietti's solution per 10 c.c. of 
bouillon and suspension. The organism was found in 800 c.c. and upwards of water. Owing to there being so few organisms in the water that can withstand the action of Parietti's solution, transfers from the primary tubes, as advised by Hankin, were found to be unnecessary. Bact. coli commune grew quite freely.

In Elsner's potato gelatine, colonies were obtained on the plates infected with the equivalents of 20 c.c. of water and upwards, and on the potato medium the colonies appeared to consist of two kinds. They were found to contain the same organism, the difference in appearance having been induced by surface and sub-surface growth. The separated organism, Bacterium II., which appears to be an ally of Bac. pinnatus, grows sparing at $37^{\circ} \mathrm{C}$, and, probably, would not have been separated by any method that necessitated the employment of this temperature.

Marpmann's citric acid gelatine entirely excluded the bacteria and in their place there was obtained a luxuriant culture of moulds, among which were Mucor racemosus and Pericillium glaucum. There were also many pink colonies of the common pink yeast. The action of $2 \%$ sodium carbonate in an agar medium at $37^{\circ} \mathrm{C}$. was not tried because agar with $0.75 \%$ sodium carbonate proved to be too alkaline a medium for the organisms of the water. The latter amount of carbonate was, I believe, recommended by Burri some years ago, and was employed in Stutzer's laboratory to indicate roughly the pollution of a water. Alkalised gelatine remained sterile, a circumstance that was to be expected from the behaviour of the alkaline agar.

In the application of Theobald Smith's method gas developed with a minimum quantity of 100 c.c. of water. The evolution was slow; but when the fermenting fluid was inoculated into fresh glucose bouillon, gas was given off vigorously. From the tube with the minimum water infection, several organisms which reddened litmus-lactose-agar were separated. Some of these lost their red colour, the bacteria producing first acid and then alkali. Bact. miniaceum was separated owing to the reddish colour of the colonies. Bact. sinuosum reddened litmus and produced gas 
from lactose in an agar medium. Mic. pyogenes $\gamma$ albus and Bacterium III., both of which reddened litmus, were also separated.

In preparing the medium for Pake's method sodium formate is employed. This salt could not be obtained in Sydney, so it was prepared by distilling glycerine with oxalic acid, neutralising with sodium hydrate and recrystallising. Fermentation took place in all the tubes which contained the equivalent of amounts of water varying from 80 to 1600 c.c. Plates prepared from all the tubes showed the constant presence of a gelatine-liquefying bacterium, Bact. cloacce, while a second non-liquefying organism, which proved to be Bact coli commune, occurred only in the largest quantity.

In reviewing the various methods for the separation of Bact. coli commune, the most serviceable appear to be Pake's and Parietti's. The easier method is undoubtedly the latter, and a ratio of 8 drops (equivalent to 0.22 c.c.) to 10 c.c. of bouillon and suspension appears to be the best for the purpose. Bact. coli commune was found in the Sydney water when quantities of 800 c.c. and upwards were employed, and when the water had a temperature of $22^{\circ} \mathrm{C}$. It is to be noted, however, that the organisms have a low vitality, since they cannot withstand over 9 drops of Parietti's solution per 10 c.c., and also they succumb to carbolised meat-extract at $42^{\circ}$. I have separated Bact. coli commune from faeces with 12 drops per 10 c.c., and the separated organisms grew in carbolised meat-extract at $42^{\circ}$. The low vitality of the water coli is undoubtedly due to a prolonged existence in the water.

The cultural characters of the organisms which were isolated and which have not already been described in the first paper are described in the following paragraphs.

\section{Micrococcus pyogenes $\gamma$ albus, Rosenbach.}

A non-motile coccus occurs in groups; the individuals measure 0.6-0.7 $\mu$ and are not decolorised when treated by the Gram method. On the gelatine plate the colonies grow as white points, which, 
when magnified, appear circular and opaque. In seven days the colonies, which remain punctiform, are surrounded by a zone of softened gelatine, and microscopically they are seen to have a rough outline and a margin like a yeast colony. The gelatinestab becomes filiform and faintly tuberculate. On agar the stroke is porcelain-white and remains narrow; the margin is lobular, and the growth spreads irregularly at the base. There is a good growth upon potato, but it is indistinguishable from the medium. Bouillon becomes turbid and forms a coherent sediment, but no film. Milk is coagulated and the reaction becomes acid. The culture on litmus-lactose-agar reddens the litmus, but does not produce gas in the medium. Nitrate is reduced to nitrite, indol is formed in bouillon, and gas is not produced from glucose.

The organism was separated by Jordan's method on account of its reddening litmus. It appears to be Mic. pyogenes $\gamma$ albus, Rosenbach.

\section{Bacillus mesentericus niger, Lunt.}

This member of the potato bacilli is a motile rod, with rounded ends, and measures $0 \cdot 6: 1 \cdot 7-3 \mu$. It forms oval central spores, and is stained by Gram's method. The growth upon potato is very much folded and dry; it soon covers the entire surface, and becomes black in colour. The potato is also blackened. The stroke on agar is at first translucent-white and gummy; it is irregularly raised, but has a practically straight margin and smooth edge. The condensed water becomes covered with a tough film. The upper smooth and shining part of the agar growth gravitates into the dry and rough lower portion. The medium slowly becomes black, and the growth grey-black. Litmus-lactose-agar is not reddened. Gelatine is liquefied; the colonies have a white centre and margin, and as they grow older white rays stretch out beyond the liquid margin. The stab in gelatine is filiform below a tubular liquefied area; there are no lateral processes. The liquefaction becomes stratiform, and a strong film forms on the surface. No gas is produced from glucose. The lower layers of the bouillon culture remain clear, 
while the upper layers become turbid and a white wrinkled film forms on the surface. The film darkens, and a black pigment is diffused into the upper layers. A strong indol reaction was obtained. No nitrite is formed from nitrate. Milk is first thickened, then the casein is peptonised. The colouring matter is not quinone, since no blue colour is obtained with potassium iodide and starch in acid solution. The black pigment is not formed in gelatine or milk.

The organism was separated by means of Parietti's solution

\section{Bacterium I.}

The organism is an actively motile cocco-bacterium measuring $0.4: 0.6 \mu$; it does not stain by the Gram method. When free to grow upon agar, the colonies become amœboid and translucent or iridescent white. The processes when magnified are seen to have a semilunar shaded tip like a finger-nail. The stroke on agar is porcelain-white, raised and glistening; the base is spreading, the margin irregular, and the edge smooth. In old cultures a brownish colour diffuses into the medium. Litmus-lactose-agar is unaffected. In gelatine the liquefying colonies are circular and crateriform with a white centre. Microscopically the centre is coarsely granular and the margin indefinite. The stab in gelatine becomes saccate, and the liquefied medium turbid, without film or precipitate. Gas is not produced from glucose. Bouillon becomes turbid and forms a sediment, but no film; the indol reaction was obtained. Nitrates are reduced to nitrites. Milk is coagulated at $37^{\circ}$ with a neutral reaction. On potato a raised, irregular, dry, yellowish-white layer is formed; the colour becomes ivory-white and moist glistening.

This bacterium apparently differs in size only from Bac. aquatilis communis, Zimm. It was found in the tube containing 7 drops of Parietti's solution per 11.5 c.c. of suspension and bouillon (300 c.c. water). If the organism is the same as Zimmermann's, it seems peculiar that the disinfectant should have permitted the growth of what is described as the commonest water bacterium. 


\section{BACTERIUM II.}

The organism is a short motile rod with rounded ends and measures $0 \cdot 4: 0 \cdot 8-1 \cdot 2 \mu$; it is decolorised by Gram's method of staining. On gelatine plate the colonies are round, white, and moist glistening. When magnified they appear rounded, light brown, granular, and smooth-edged.

The gelatine-stab is filiform with a restricted, lobular, flat nailhead. No gas is produced from glucose. The stroke on agar is white, moist glistening and slightly iridescent; it slowly widens laterally and spreads out at the base; the condensed water has no film. Litmus-lactose-agar is not affected. Bouillon becomes turbid and forms a sediment and a slight film. A slight indol reaction was obtained; nitrates were not reduced. Milk is not coagulated, and the reaction is unaltered. On potato the growth is irregular, slightly raised, pale buff in colour and with a fatty appearance; the growth becomes buff and moist glistening. The organism grows slowly at $37^{\circ} \mathrm{C}$.

This bacterium was separated by Elsner's method. Its indifference to milk and glucose places it among the typhoid group of bacteria. Its nearest ally appears to be Bac. pinnatus, Ravenal. It has many points of difference from Bact. typhi.

\section{BACTERIUM III.}

A small, oval, actively motile bacterium measures $0.3: 0.6 \mu$, and is not stained by the Gram method. The colonies on gelatine are circular, white, and moist glistening. When magnified the surface colonies are seen to be rounded, brownish, and flocose in structure; 24 hours later flocose wisps are seen extending radially from an irregular dark centre into the finely granular marginal portion; in another 24 hours the flocose wisps have become clubshaped processes. The deep colonies are rounded or lenticular, granular and opaque; the sub-surface colonies moruloid. The stab in gelatine is filiform and tuberculate, with an irregular lacerate raised and terraced nail-head. Gas is given off from glucose. The colonies on agar are thin, spreading and almost 
transparent white with an irregular or amœboid margin; they may also be rounded, thicker and translucent white. Microscopically they are finely granular. The deep colonies are uncharacteristic. The stroke on agar is thin, moist glistening, white and iridescent; the growth rapidly spreads over the agar surface and gas bubbles form in the medium. Litmus-lactose-agar becomes red excepting at the surface, which remains a persistent blue; the red colour becomes bleached and gas bubbles are formed in the medium. Bouillon becomes turbid and forms a white sediment; a slight indol reaction was obtained. Nitrates are reduced to nitrites. Milk is coagulated with a faint acid reaction. On potato a brownish raised layer is formed and the medium slowly becomes of the same colour as the growth.

As the gelatine in stab culture was found to be fluid after a month's growth, the organism may be Bact. Kralii, Dyar. The gelatine-liquefying property of the organism is indicated also by the bleaching action upon litmus.

\section{Bacterium Cloace, Jordan.}

The bacterium is an actively motile rod with rounded ends; it varies in length and breadth, measuring $0 \cdot 6-0 \cdot 7: 0 \cdot 8-1 \cdot 4 \mu$; longer forms also occur. It is not stained by Gram's method. On gelatine the colonies are punctiform and microscopically coli-like, but they soon become shallow liquefied depressions. The stab in gelatine is napiform and becomes saccate; the upper layers of the liquefied medium are turbid, the lower layers clear with floating floccules. No film is formed. Gas is produced in glucose-gelatine. The colonies on agar are indefinite, white and watery, and surrounded by a cluster of small transparent islet colonies. Microscopically the structure appears homogeneous. The deep colonies are uncharacteristic. The stroke on agar is narrow, raised and translucent white; the agar surface is covered with a watery growth like a film of condensed water. The litmus in litmuslactose-agar culture is bleached in the deep parts of the medium and deep blue at the surface. Bouillon becomes turbid and forms a slight precipitate and film; a slight indol reaction was 
obtained. Nitrates were strongly reduced to nitrites. On potato the grow th was light brownish-yellow scarcely distinguishable from the potato, but afterwards it became darker, raised and spread over the surface. Milk was coagulated at $37^{\circ}$ with a neutral reaction.

This organism was separated by Pake's method as well as by those of Bandi and Parietti. The first colonies on gelatine by Pake's method were like those of Proteus mirabilis, but the formation of cochleate strands from the margin of the colonies had ceased by the third transfer in ordinary media and the type became stable. It appears to be Bact. cloace, Jordan, a gelatineliquefying form of Bact. coli.

Bact. coli comune, Escherich.

The bacterium is a short, stout motile rod with rounded ends; it measures $0 \cdot 55-0 \cdot 6: 0 \cdot 9-1 \cdot 8 \mu$, and is not stained by Gram's method. The flagella are long and generally 5 to 9 in number, arising from places around the organism. The colonies on gelatine are punctiform, but became flat, spreading, white, and moist glistening with a raised centre. Microscopically the deep colonies are yellowish-brown, circular and finely granular with a smooth edge; when crowded upon the plate they appear zonate. The surface colonies appear lacerate-erose and grained (the type of coli). The stab in gelatine is filiform with a flat, thin, translucent white, irregularly spreading nail-head. Gas is given off copiously in glucose-gelatine; the gas collected in the fermentation tube contained 1 part carbon dioxide and 2 parts hydrogen. The colonies on agar are translucent white, round, moist glistening and raised centrally. Microscopically the colonies are rounded, finely granular and smooth-edged. The older colonies have a zone of large granules near the margin. The stroke on agar is white, moist glistening and broad, the margin smooth. Litmus-lactoseagar is permanently reddened and gas bubbles are distributed throughout the medium. Bouillon becomes turbid and forms a 
white sediment and a film. The indol reaction was obtained, and nitrates were reduced to nitrites. Milk is coagulated with an acid reaction. On potato the growth is spreading, raised, moist glistening and yellowish-brown.

This organism, which is undoubtedly $B$. coli commune, was separated from 1600 c.c. of water by Pake's method, and also from 800 c.c. of water by 8 drops of Parietti's solution per $10 \mathrm{c}$ c. of bouillon and bacterial suspension. 


\section{$2 \mathrm{BHL}$ Biodiversity Heritage Library}

Greig-Smith, Robert. 1901. "Contribution to the bacterial flora of the Sydney water supply, II." Proceedings of the Linnean Society of New South Wales 25, 740-759. https://doi.org/10.5962/bhl.part.12190.

View This Item Online: https://www.biodiversitylibrary.org/item/30484

DOI: https://doi.org/10.5962/bhl.part.12190

Permalink: https://www.biodiversitylibrary.org/partpdf/12190

\section{Holding Institution}

MBLWHOI Library

\section{Sponsored by}

MBLWHOI Library

\section{Copyright \& Reuse}

Copyright Status: NOT_IN_COPYRIGHT

This document was created from content at the Biodiversity Heritage Library, the world's largest open access digital library for biodiversity literature and archives. Visit BHL at https://www.biodiversitylibrary.org. 